\title{
Understanding Public Sector Employees' Motivation: What Makes Them Inspired?
}

\author{
Carole Serhan \\ Dept. of Business Management and Administration, University of Balamand \\ PO Box 100, Tripoli, Lebanon \\ E-mail: carole.serhan@balamand.edu.lb
}

Eliane Al Achy

Dept. of Business Management and Administration, University of Balamand PO Box 100, Tripoli, Lebanon

E-mail: eliane.achy@std.balamand.edu.lb

Eva Nicolas

Dept. of Business Management and Administration, University of Balamand PO Box 100, Tripoli, Lebanon

E-mail: eva.nicolas@std.balamand.edu.lb

Received: Jan. 19, 2018 Accepted: Feb. 3, 2018 Online published: Mar. 3, 2018

doi:10.5296/ijhrs.v8i1.12758 URL: https://doi.org/10.5296/ijhrs.v8i1.12758

\begin{abstract}
This article examines the ranked importance of employment motivational factors within the Lebanese public sector. A qualitative interview with employers and employees of the Lebanese public sector is carried out to get their responses on what they consider the best factors that motivate them at work. In this light, the article sets to identify the most ranked factors out of ten motivational factors deemed to affect employees' motivation in public sector organizations. The analysis from the empirical findings (using NVivo software) showed that remuneration and working conditions are key to higher employee motivation. Promotion, autonomy, participation in decisions, work social relationships and communication should be considered as well. Finally, guidelines and recommendations for implementing
\end{abstract}


research findings with respect to remuneration and suggestions for assessing working conditions are provided.

Keywords: motivation, satisfaction, employees, public sector, Lebanon

\section{Introduction}

A key aspect that distinguishes the more successful organizations from the less successful ones is the motivation of their employees. Humans within the organization are tackled every day with various internal factors that work together to frame the image of the organization. This includes the remuneration, working conditions and workplace relations, the strategies of communication and management, the level of information, the reward system, and decision-making chances (Vallerand et. al, 1993). All these factors affect employees' psychological states and affective behaviors at work. The work achieved by employees constitutes their job participation, which sequentially helps to build up mutual social relationships. Besides, employees set up relationships within their organizations. These mutual social relationships and the employees' attitudes towards the organization help to develop a positive organizational atmosphere that is deemed to motivate employees at work (Gradišar, 2009).

Motivation is the result of a complex process that involves personal characteristics, core job dimensions, labor market conditions and work environment. Positive core job dimensions are very important for an organization because they represent a mean for employees' motivation, which leads to an increase in productivity as well. These dimensions are an incentive for organizational progress and development (Roussel, 2000, 2001).

In Lebanon, public sector administrations are rather bureaucratic, i.e. the form of organization which focuses on the skills and neglects the importance of communication between staff as a motivator. Also, public organizations in Lebanon are characterized by routine tasks and are highly specialized, while having limits on employees' initiatives (Dagher, 2010).

Similarly, the salary of employees working in the public sector is very low compared to international standards. This is seen today by employees' strikes where they ask for an increase in salary. In addition, the promotion in Lebanon, and especially at the level of the high rank functions of the public sector, does not pass without political interventions. This is also considered as a discouraging factor, as said Georges Clemenceau: "There's only one way to fail, it's giving up before succeeding".

At this point, one question is raised: Are job characteristics an essential determinant of motivation for public sector employees in Lebanon? The significance of this research lies in the originality of the topic where no scholars have previously discussed this issue in Lebanon though the great need to identify the consequences of the poor working conditions' menaces and to analyze the most probable effects of many discouraging factors such as low pay, difficult promotion opportunities and complicated and unfair reward systems and others on the productivity of public sector organizations. In light of this gap and given the importance of the subject of study, the purpose of this research is to contribute to the field of study by examining the general motivation concept, its different definitions, sources and origins, over viewing the Lebanese government, defining how the Lebanese public organizations work and 
the main problems it faces and analyzing the effects of these problems on the public sector employees' motivation. This should be of a great value to scholars, practitioners and legal authorities in Lebanon and elsewhere allowing them to find means to increase the motivation of employees in the public sector organizations which in turn is deemed to improve the quality of the various public organizations' services.

\section{Literature Review}

Management is the ability of motivating others to get work done right. Getting work done right is not always an easy mission but is associated to human conduct. An organization success is highly affected by the conduct and concern of its employees. Thus the objectives of an organization are realized through the correct conduct of its employees in a desired way (Crozier, 1987).

Prior to giving directions to the employees, the reasons for such behavior should be identified since the management can well motivate the employees based on such reasons. Knowing that motivation is the process of stimulating people to act or behave so as to accomplish the goals; in the work goal context, the psychological factors stimulating employees' behavior can be summarized by the desire for money, success, recognition, job-satisfaction, team work, etc. (ibid.)

One of the most important functions of management is to create willingness amongst the employees to perform in the best of their abilities. Therefore the responsibility of a good leader is to stimulate interest in employees' performance in their jobs. The process of motivation consists of three stages: (1) a felt need or drive, (2) a stimulus in which needs have to be aroused, and (3) when needs are satisfied, the satisfaction or accomplishment of goals. Therefore, motivation is a psychological phenomenon implying that individuals' needs have to be tackled by framing an encouragement plan (Dagemais, 2005; Serhan \& Tsangari, 2016b, 2017).

There are several sources of motivation for employees at work whose degree of importance differs from one company to another, from one leader to another and from one employee to another. These sources are: (1) goal setting and communication, (2) gratitude, (3) recognition at work (recognition of the person, skills, results...), (4) maintaining team spirit, and (5) compensation (Hsu \& Chen, 2012).

The in-depth studies (Laufer, 1985; Levy leboyer, 1998; Mercier, 2000; Reix, 2000; Zakaria, 2012) related to motivation emphasized the importance of the distinction between intrinsic and extrinsic motivation. Intrinsic motivation is defined as executing an action or behavior as one gets pleasure from the activity itself whereas extrinsic motivation refers to motivation through the rewards of doing a job.

Furthermore, motivation and job satisfaction are two inseparable concepts, but in the remuneration policy the human resource manager must distinguish between these two terms.

Satisfaction is an indicator of motivation but never a cause of motivation. It reflects the feelings affected by employees in a work situation. Motivation is what drives to action, while satisfaction is what meets the demand of a need or desire. In sum, an employee can be satisfied without motivation, but it is difficult to be motivated without a minimum of satisfaction (Zakaria, 2012; Serhan et.al, 2016). 
In addition, for a better understanding of the motivation processes, it is necessary to review the theoretical approaches and theories related to motivation among which we can distinguish the theories of content (mostly related to the satisfaction of the needs), cognitive process based theories (pertaining to the orientation of the individual's behavior at work) and the theories of feelings' development (related to self-regulation) (Zeytinoglu \& Denton, 2005).

Content theories are based on meeting needs. These theories focus on the needs of individuals and the conditions that drive them to meet those needs. They are focused on the intensity of motivation. Several authors and theorists have discussed these content theories. The most important of these authors are Abraham Maslow (1943), Clayton P. Alderfer (1969), Frederick Herzberg (1959), David McClelland (1961), Hackman and Oldham (1976) and others.

Beginning with Maslow and Herzberg, who are well known for their contributions to motivational content, these two are among the best-known authors in the field of needs theorization. Both have sought to structure the sources of motivation, either by putting them in the form of a pyramid (by the theory of needs), or by opposing them in a dialectical way (by the theory of two factors).

Maslow (1943) distinguishes five groups of needs that prioritizes and ranks them in a pyramid in order of priority: (1) physiological needs: this is the first most basic level; these requirements are called "primary needs" and are designed to ensure the survival and food, (2) security or safety needs: these needs (mental, economic, physical) depend on the expectations of everyone in terms of moral and physical security, (3) membership needs: these are the needs of an individual to belong to a group, a community, have friends, etc. (4) esteem needs (recognition): These are the needs for recognition, to be respected and associated by others, and (5) need for self-fulfillment: This need is the willingness of an individual to achieve, to communicate with others and to help improve the world "to become more and more what we are". Alderfer ERG Theory was proposed by Alderfer in 1969. It states that the feeling of need is the one that motivates the individual and distinguishes three types of needs: (1) the needs of existence they are all material needs, primary and physical needs, (2) the sociability needs (relatedness): these are the needs of interpersonal relationships, the set of social needs, and (3) the development needs (growth): these are the needs of significant achievements, creation, use and development of skills (Alderfer, 1969). However, Frederick Herzberg (1959) in his theory named the Bi-Factorial Theory proposed the distinction between two factors behind motivation, the factors capable of generating satisfaction at work, and those which give an absence of dissatisfaction at work. Herzberg distinguishes: (1) factors generating satisfaction and called "motivators" such as remuneration, recognition, personal development, etc., and (2) factors whose absence generate dissatisfaction such as the quality of the environment, working conditions, hierarchical relations within the company, etc. According to Herzberg, to motivate employees it is necessary to work on motivating factors (satisfaction factors). Herzberg's model has been very popular for its simplicity and originality. However, McClelland's Theory of Motivation proposes that the individual is inhabited by three kinds of needs that are identified as influencing motivation. These needs are: (1) the need for affiliation (membership) which is the need to have interpersonal relationships, and desire to be accepted by a group, (2) the need for power which is the need to influence the behavior of others, and to direct and control the external environment, and (3) the need for 
fulfillment which is the need to achieve the objectives set (McClelland, 1961). Finally, Hackman and Oldham Job Characteristics Theory proposes the job characteristics model which identifies five core job dimensions described as follows: (1) the diversity of skills needed, (2) the identity of the task, (3) the importance of the task, (4) the autonomy, and (5) the feedback. These five core job dimensions are supposed to affect the employees' psychological states at work and in turn to influence their personal and work outcomes including motivation (Hackman \& Oldham, 1980).

Cognitive process based theories, as opposed to content theories, study the orientation of the individual's behavior at work, the mechanisms that lead to motivation, and the motivational process. Among these theories, Vroom's theory of expectations is the best one to find applications to the managerial domain. This theory is stated by Victor Vroom (1964). It discusses the behaviors of individuals that are the result of a reasoned choice. According to this theory, there are three types of perceptions: (1) the valence which is the value that the individual gives to the rewards obtained, (2) the instrumentality which is the probability that the expected performance leads to consequences and results, and (3) the expectation.

Finally, self-regulation theories (SRT) are a scheme of organized personal management that involves the procedure of directing one's own thoughts, behaviors, and feelings to achieve objectives. Two theories have been chosen from this paradigm, for they have the greatest impact on management. These two theories are: (1) goal setting theory of motivation and (2) self-determination theory.

Goal setting theory of motivation was enunciated by Locke (1968) who stated that clear goals and appropriate feedback motivate employees. In his theory, he highlighted the importance of working toward a goal as a major source of motivation which in turn improves motivation. However, this theory encountered limits when the goal set is too difficult to achieve, when the simple goal setting is not enough to motivate people, and when individuals do not have a strong need for achievement.

Self-determination theory is a theory of motivation as well. It was created by Deci and Ryan (1985) who addressed that individuals are motivated when they feel they are competent and independent.

Thus, in sum, the success of a business is not only linked to its financial results and turnover but is mainly related to how much it succeeds in motivating, retaining and attracting its employees.

Notwithstanding the aforementioned theories and definitions concerning motivation, there is a significant body of literature showing the various and sometimes contradictory point of views concerning the relationship of various factors and motivation (Serhan \& Tsangari, 2015; 2016a; 2017). Despite these contradictions, the research studies devoted to tracing the linkages between these factors and motivation has grown significantly in recent years. In order to better understand these factors, a set of job characteristics are considered. These characteristics are defined below with reference to motivation.

First of all, over the last decades, many research studies around the world have been carried out to examine the impact of remuneration on motivation (Lee \& Lee, 2012; Mokaya et al., 2013; Tourani \& Rast 2012). Remuneration can be both a motivator and a discouraging factor if it is deemed to be insufficient. Similarly, it does not motivate individuals in the same way; it 
differs from one individual to another. Pay can be considered as a discouraging factor more than a motivator and this is explained by the fact that a high salary produces short-term satisfaction and is very quickly forgotten, but unequal salaries for doing similar jobs is absolutely discouraging and cannot be forgotten.

Second, working Conditions affect the motivation of employees. Indeed, working in pleasant and spacious premises where the environment is healthy and working hours are reasonable allowing balancing between work and private life increases the motivation of employees (Sehgal, 2012).

Third, the company's culture is a very important element in the organization and a key factor for employees' motivation. It helps employees to increase their stay at work (Hofstede, 2010). Fourth, management and Communication are very important in the process of motivation. Strong communication limits conflicts between employees at work. Similarly, communication between employees and managers improves recognition, value and respect. Work social relationships facilitate communication and in turn help to increase motivation (ibid.).

Fifth, development of professional competence is an essential factor of motivation, such as training that allows employees to be more effective and autonomous in their work (Jex \& Britt, 2008).

Sixth, employee participation in the decision making and autonomy at work are considered as a key factor affecting motivation. Indeed, all conducted research studies concerning the relationship between employee participation and motivation showed positive results. Tourani and Rast (2012) suggested that both employees' participation and autonomy have significant and positive effect on employees' motivation.

Seventh, promotion which refers to rewards prearranged for highly dynamic employees affect employees' motivation (Dizgah et al., 2012; Ghaziani et al., 2012). Scholars e.g. Naveed et al. (2011) concluded that there is a positive and significant correlation between promotion and motivation and Kosteas (2010) stated that even employees who expect to get a promotion report high levels of motivation.

Now that motivation has been overviewed, a complete description of the Lebanese public sector is primordial allowing a better understanding of the subject of study.

Public organizations have a primary mission of public service where their activity is intended to satisfy a need of general interest. The state is the largest employer in public organizations. It is responsible for social and economic development of the nation. The mission of public organizations must be applied correctly within budget constraints and accurate accounting (ibid.).

The Lebanese government endures several problems of which scholars mention:

(1) The neglect of citizen's interest: Most citizens suffer from the government' interest in politicians and those in power and some civil servants. Besides, the major reason behind citizens' complaints remains the traditional working methods that are very complicated (Crozier, 1987; Dagemais, 2005).

(2) The government's tough tasks and responsibilities: Public administration is overwhelmed by various tasks and responsibilities. However, these responsibilities do not reflect the 
priorities of a developed state. In most areas, private sector institutions and non-governmental organizations are more able and more willing to offer services than the public sector. This is mainly due to the lack of competence of the public administration (ibid.).

(3) The public organization structure: The Lebanese government is suffering wildly from centralization and weak planning between central and local governments (such as municipalities). Indeed, the role of most municipalities is limited to just improving infrastructure and services without being able to participate in local development decisions. In addition, centralization has a negative effect on administrative procedures when it makes goals achievements more complicated, slow and costly (ibid.).

(4) The lack of modern technologies: The public administration systems do not use communication technologies and information. The supply of computer equipment and the training of officials in this area have taken a lot of effort to be applied. Besides, the technologies that can provide a better way to improve the degree of feasibility and translucency are not used and the exchange of information is done in a traditional way (Crozier, 1987; Dagemais, 2005).

(5) The lack of skills: Most of the public administration officers are old aged where most of them exceed 52 years and this lowers the chances of accepting and understanding changes. The private sector attracts people of high specialization for they offer higher wages than the state, which results in a lack of important skills in information technology, management, planning and statistics (ibid.).

(6) The lack of control: Control systems and accountability in the administration are ineffective despite the several disciplinary and supervisory bodies within the Lebanese government, such as the Council of Public Employees, the Central Inspection, and the General Disciplinary Board. Many irregularities and low levels of services are noticed where departments do not present reports concerning their activities every six months in accordance with the laws (ibid.).

(7) The corruption: Corruption in government is becoming more serious. Several factors are the basis of corruption in public administration such as the lack of effective control and accountability, extravagant centralization, political interference in the work of public administration where there are corrupt officials protected by some influential politicians. So, corruption is protected by the structure of patronage under the guise of sectarianism, whether in administration or politics (ibid.).

These several problems represent a tough burden for the Lebanese public organizations. They reflect the traditional and inefficient managerial styles where low wages and bad working conditions are offered and where lack of communication, corruption and lack of technologies are predominant. These are considered as discouraging factors which result in decreasing the stay of efficient, ambitious and productive employees who are very easily attracted by the private sector.

\section{Data and Methods}

Knowing that the present research is descriptive in its nature, the main purpose of this study is to answer the research questions that aim to depict the present situation regarding the 
motivation at the Lebanese public sector. This type of research offers knowledge about the extent conditions and highlights the past or present circumstances so as to create a complete and inclusive understanding of the subject of study and to provide recommendations helping to build a healthier future for public sector employees.

\subsection{Sample Data}

In order to collect the data for assessing the factors impacting employee motivation at the Lebanese public sector, a sample of five respondents were asked to take part in a semi-structured interview. The population for the extent research is directors and employees working in the public sector of Lebanon. The choice of this diversified sample facilitated the collection of significant information that combines the different point of views of employees and directors regarding the issues of motivation in their organizations and to allow the completion of the comparative approach between the two, which will bring many concrete answers.

The present study uses a non probability sampling technique that is purposive sampling. Purposive sampling is a sampling technique that obtains and collects the significant information from the sample or the unit of the study that are chosen on purpose for their knowledge about the subject of study. Purposive sampling is normally used for collecting the most accurate and relevant information when the population is not large (Hemming et al, 2011). It guarantees that the sample respondents enjoy two main qualifications to participate in the semi-structured interview. First, the sample respondents should have enough knowledge about their jobs. Second, they should be working in any public sector organization of Lebanon.

As aforementioned the sample for this study is divided into two parts: (1) directors and whose sample consists of two directors and (2) employees of whom the sample is composed of three employees. All work in the public sector.

Five interviews were achieved with two directors and three employees working in different areas of the public Lebanese industry making sure not to focus on one area and to have different point of views regarding the characteristics and implementation of motivation in these different organizations.

The final retained sample for directors is presented in Table 1 and the final retained sample for employees is presented in Table 2 while respecting the anonymity of these.

Table 1. Sample of Directors

\begin{tabular}{l|l|l|l|l}
\hline Organizations & Name & Function & Age & Sex \\
\hline $\begin{array}{l}\text { Ministry of Higher } \\
\text { Education }\end{array}$ & $\begin{array}{l}\text { Director } \\
1\end{array}$ & Director of Public School & 62 y & Female \\
\hline Ministry of Electricity & $\begin{array}{l}\text { Director } \\
2\end{array}$ & $\begin{array}{l}\text { General Director of Electricity of } \\
\text { Lebanon (EDL) }\end{array}$ & $53 \mathrm{y}$ & Male \\
\hline
\end{tabular}


Table 2. Sample of Employees

\begin{tabular}{l|l|l|l|l}
\hline Organizations & Name & Function & Age & Sex \\
\hline Bank of Lebanon & $\begin{array}{l}\text { Employee } \\
1\end{array}$ & Consultant & $50 \mathrm{y}$ & Male \\
\hline $\begin{array}{l}\text { Ministry of } \\
\text { Finance }\end{array}$ & $\begin{array}{l}\text { Employee } \\
2\end{array}$ & Treasurer / Cashier & $59 \mathrm{y}$ & Male \\
\hline $\begin{array}{l}\text { Ministry of Higher } \\
\text { Education }\end{array}$ & $\begin{array}{l}\text { Employee } \\
3\end{array}$ & Teacher & $28 \mathrm{y}$ & Female \\
\hline
\end{tabular}

\subsection{Instruments and Measures}

The semi-structured interviews of the extent study report two main purposes: (1) to analyze the relation of different factors affecting motivation in the public sector and (2) to collect information about the different features of the respondents that can help to better assimilate the variations in different categories. The semi-structured interview contains seven questions. Question 1 includes different personal variables. This section will obtain the respondent's information about gender, age and work experience and status. The remaining questions include the hidden factors that are central in the existing study. These factors include remuneration, working conditions, promotion, work social environment, autonomy, participation in decisions and communication. These questions are developed based on the extent literature.

The interview guide is a translation of research hypotheses. Knowing that it consists of seven questions, the interview guide was asked to two directors and three employees from different areas of the public sector to have a rich and comprehensive study. These questions fall into four themes as shown below:

Theme 1: Personal Information

Question 1: How old are you? For how many years have you been working in the public sector? What is your status at work?

Theme 2: General Order Information

Question 2: What do you think about the concept of employee motivation?

Question 3: Do you believe that employee motivation is affected by the policies and strategies adopted by the management of human resources? Or do you think it is a voluntary act that comes from the employee himself?

Question 4: In your opinion, what are the main factors affecting employee motivation? Can you classify these factors from most important to least important?

Theme 3: Implementation of the Motivation in the Company

Question 5: What are the different motivational techniques used within your business?

Theme 4: The Viewpoint of Respondents

Question 6: If you were the only person who has the right to decide the HR policy, what 
motivation techniques do you use and why?

Question 7: What is your point of view regarding the effect of new employee motivation atypical techniques (rest rooms, sports halls, seminars, etc.)?

Data analysis was conducted through using Nvivo, which helped to store data in a systematic way, to provide hierarchies and structures of data, and to conduct analysis.

\section{Results and Discussion}

This segment of the study presents the analysis of results obtained from the interviews carried out with directors and employees. Besides, a comparative analysis of the results received from directors and employees is achieved in order to achieve a cross-analysis of responses between them, which will help reach a reasonable conclusion.

\subsection{Results of the Study}

Analysis of results is divided into two parts. The first part concerns the results received from interviewing the directors and the second part analyses the results from the employees.

Concerning the directors, results received are divided into themes and presented as follows:

Theme 1: Personal Information

Question 1: How old are you? For how many years have you been working in the public sector? What is your status at work?

Respondent1: Director 1 is a Public School manager. She is 62 years old and has 22 years of experience in this business. She began her carrier as an instructor and then after a few years she became a director and was fortunate to evolve by following some training programs.

Respondent 2: Director 2 is a Regional Director at Electricity of Liban. He is 53 years old and has 33 years of experience in this business. He began his career in the same position.

Theme 2: General Order Information

Question 2: What do you think about the concept of employee motivation?

Respondent 1: As per Director 1, employee motivation is primarily the fact of working happily for a company. In the educational field, motivating employees is to (1) encourage them in a continuous manner, (2) give them a certificate of appreciation when deserved, (3) always grant meetings, and (4) make good use of moral stimulus.

Respondent 2: As per Director 2, employee motivation is a result of a clear vision about the future of the company. It happens when employees show a great interest about the objectives of the company and focus on its goals and missions, and certainly know their positions and understand clearly what the company expects of them.

Question 3: Do you believe that employee motivation is affected by the policies and strategies adopted by the management of human resources? Or do you think it is a voluntary act that comes from the employee himself? 
Respondent 1: According to her, employee motivation comes from the employees themselves and at the same time the direction of HR. It is an act that comes from the interaction between the two. The HR policy plays a very important role in terms of motivation. This department must detect all the discouraging factors among employees to find corrective measures by working to motivate them. In addition, the employee should help the management of HR as well because if the feeling to develop and evolve the work does not come from inside, policies are useless.

Respondent 2: According to him, the character and personality of the employee must be taken into consideration. Each employee has a different and special personality. There are employees who have problems and have an unmotivated character so here springs the role of HR management to understand and motivate.

Question 4: In your opinion, what are the main factors affecting employee motivation? Can you classify these factors from most important to least important?

Respondent 1: According to the director, the top five sources of motivation are:

- $\quad$ Promotion: the promotion is a motivator. A dynamic staff who achieves a higher level of production and meets the management expectations is a motivated employee.

- $\quad$ Remuneration or pay: Compensation plays a very important role in the motivation of employees; this pushes them to work better and improve the quality of work.

- Working conditions: The main problem in public schools is the old buildings in general. The rooms are very narrow; they need new furniture (new benches, chairs, tables ...) and new technological equipments such as smart tablets that help a lot the teacher to give the information in a clear and easy way. These working conditions mainly de-motivate employees when they are not well.

- $\quad$ Participation in decisions: It is very necessary to provide opportunities for teachers to participate in decisions concerning the company and give attention to their point of views because this motivates them when they feel they are recognized to the company and they are an effective part of it.

- Maintaining team spirit: It is very primordial to keep the team spirit in all departments and areas of the company and a good contact with the directors and managers is also very important.

Respondent 2: According to the director 2, three main sources of motivation exist:

- Promotion and good pay: The possibility of an evolution in work and an increase in salary is a source of motivation for almost all employees.

- Working conditions: The working conditions are very important in terms of motivation. Employees spend half their day in the workplace and if it is not well organized and comfortable, the production and motivation of the employee will decrease. 
- Autonomy: The employee must enjoy an acceptable degree of autonomy in their daily tasks because it is a key source of motivation.

Theme 3: Implementation of Motivation in the Company

Question 5: What are the different motivational techniques used within your business?

Respondent 1: In general public schools, motivational techniques are neglected by the state; they even do not exist sufficiently.

Respondent 2: The only motivation technique used by the state to motivate employees is training. It must be mentioned that there is a clear lack of motivation techniques related to compensation.

Theme 4: The Viewpoint of Respondents

Question 6: If you were the only person who has the right to decide the HR policy, what motivation techniques do you use and why?

Respondent 1: Respondent 1 stressed the importance of applying continuous training programs to teachers so they can know and understand their work. In addition, it would be very helpful to organize meetings on an ongoing basis, to listen to employees and to encourage communication for it allows improving and enhancing personal relationships among employees themselves and even relationships with professional levels.

Respondent 2: Respondent 2 has nothing to say in relation to this question for he considered this as already answered in Question 4.

Question 7: What is your point of view regarding the effect of new employee motivation atypical techniques (rest rooms, sports halls, seminars, etc.)?

Respondent 1: All these atypical forms of employees' motivation are quite positive and interesting. They are excellent initiatives allowing employees to make life easier in the workplace and to free their mind.

Respondent 2: New employee motivation techniques are very positive for the company and for the employees at the same time. However, the limits of available budgets have always been a barrier.

Concerning the employees, results received are divided into themes and presented as follows:

Theme 1: Personal Information

Question 1: How old are you? For how many years have you been working in the public sector? What is your status at work?

Respondent 1: Respondent 1 is a consultant at the Bank of Lebanon. He is fifty years' old and has twenty years of experience in this area.

Respondent 2: Respondent 2 is a cashier in the Ministry of Finance since thirty years and is fifty nine years' old. 


\section{Macrothink}

Respondent 3: Respondent 3 is a teacher in the Ministry of Higher Education. She is twenty eight years' old and has 7 years of experience in the public school.

Theme 2: General Order Information

Question 2: What do you think about the concept of employee motivation?

Respondent 1: The motivation of employees is essential to ensure a good image to the bank while respecting the standards and laws that make them more loyal customers firstly and most comfortable employees on the other hand.

Respondent 2: Motivation is to make training for employees so they can know their jobs well, to improve the quality of work and be updated regularly; in addition to increasing salaries continuously.

Respondent 3: Motivation arises when students succeed in their exams, understand everything explained in the classroom, and benefit from good communication skills allowing employees to be motivated in their work and to give more effort to provide a better climate for students.

Question 3: Do you believe that employee motivation is affected by the policies and strategies adopted by the management of human resources? Or do you think it is a voluntary act that comes from the employee himself?

Respondent 1: Employee motivation can be an inner feeling coming from the employees themselves and at the same time it can be a result of the relationship with managers at work. When the director does not give everyone what deserves this causes discontent and de-motivate employees; for that equitable intervention of the director in motivating employees is very important to ensure a good work environment .Equality at work where employees with the same qualifications receive the same pay is also considered as a major reason behind employees' motivation.

Respondent 2: An interactive relationship between the desire of the employee to be motivated and invested and between incentives of HR policy is a major incentive for many employees.

Respondent 3: There is no motivational policies adopted in the public sector and the state does not give any importance to employee motivation. There is no equality between teachers' rights and compensation benefits, where teachers with fewer qualifications might earn the same salary as the most qualified one and this is considered as a de-motivating factor.

Question 4: In your opinion, what are the main factors affecting employee motivation? Can you classify these factors from most important to least important?

Respondent 1: the main sources of motivation are the following :

- The salary and remuneration benefits: the main sources of motivation are pay and other financial benefits as they provide all employees' needs in addition to the financial services offered (such as hospitality services, subsidies for education...). 


\section{Macrothink}

- $\quad$ Coaching: coaching plays a vital role in motivating employees where good coaching provide a healthy work environment and help employees to work quietly and without pressure.

Respondent 2: the main sources of motivation are:

- Compensation: the salary and the financial aspect is the most important source which motivate the employee.

- Working conditions: Working conditions are the second main source of motivation for employees, as is the case in most public sector offices, where the office equipments such as computers, phones, photocopiers and others are very old, and these materials are out of work most of time delaying the work of the employee and preventing the finish time of operations.

- The content of work: The work content is a very important motivator. The work must be interesting and varied for it to motivate the employee to love his job. In contrast, if the work is routine, uninteresting and fulfilling the employee becomes de-motivated by this kind of work. In addition, the employee likes to change the workplace but in condition of not losing his position to get out of the routine.

- Good relationships at work and easy communication: communication and good relations with employees at work play a very important role in terms of motivation (respect, recognition...)

Respondent 3: the sources of motivation are 3:

- Salary: salary is in the first position as a primary motivator of employees. Indeed, the wage is a very essential part in motivating employees especially since all the costs are rising and this causes difficulty to meet needs.

- Compensation benefits: this is a very important factor for motivation. It can be in the form of education grants for children and hospital services.

- Coaching: the quality of supervision is a main element contributing to employee motivation. Incidentally, when the manager does not manage its department properly and does not exercise equality, the result is dissatisfaction for employees.

Theme 3: Implementation of Motivation in the Company

Question 5: What are the different motivational techniques used within your business?

Respondent 1: the manager offered a program that facilitates the work and helps to finish it in a short time. This is mainly considered as a motivational technique.

Respondent 2: the state is not interested in motivating employees, and there is no one motivational technique that has been used. However, a 500000 LBP (equivalent to 333 USD) bonus have been offered once to employees who can give an idea for the development work.

Respondent 3: there is no one single motivational policy adopted by the state. However, some 
actions were implemented, such as offering training courses for teachers to introduce them to the different software (such as Excel, Access, Power Point ...) but unfortunately they could not practice what they learned because of the lack of computer rooms in the school.

Theme 4: The Viewpoint of Respondents

Question 6: If you were the only person who has the right to decide the HR policy, what motivation techniques do you use and why?

Respondent 1: equality between the various employees where each person takes what he or she deserves is the best way to motivate employees. In addition, having the right person in the right position is another motivational factor. Finally offering bonuses for skilled employees to encourage them and make them comfortable in their work is a must.

Respondent 2: promoting good contact between the HR department and employees is very important because the two are not located in the same premises which limit the contact. Stopping the random recruiting is another must because this causes an additional expense for the State.

Respondent 3: applying a control policy while giving each teacher what he deserves is primordial in addition to distinguishing between those who are competent and those who are not.

In addition, it proposed to give bonuses to those who have made progress during the year and to punish those who do not do their mission.

Question 7: What is your point of view regarding the effect of new employee motivation atypical techniques (rest rooms, sports halls, seminars, etc.)?

Respondent 1: it is essential to ensure employees with atypical techniques and to make them motivated. For this it is proposed to put a microphone in the bank to call customers without shouting and disturbing other employees. In addition, it is suggested to provide a living room for employees to relax during their coffee break.

Respondent 2: these new types of motivational techniques are very interesting and positive for any company.

Respondent 3: all these atypical forms of employee motivation are quite positive as they allow people to be more comfortable during their work. For this, it first proposed to improve the infrastructure and the building of the public schools because they are in poor conditions, and to buy all the technological equipment such as computers ensuring a suitable technological state. Then, it is suggested to build a gym for teachers, so they can do sports during their hours of rest and to ensure a private office for each teacher and employee and to provide a library in the school so that teachers and students benefit.

\subsection{Discussion}

After completion of the analysis of interviews with directors and employees in the first section, a comparative analysis of interviews is conducted in this section, while proceeding 
first to the cross-analysis of responses between directors. Then secondly an analysis and comparison among the results collected from employees' interviews is achieved. Finally, a comparative analysis between directors' answers and those of employees is carried out.

\subsubsection{Cross-Analysis of Responses between Directors}

This analysis is divided into several parts to gather all the topics discussed. These topics are (1) concept of employee motivation, (2) employee motivation as a voluntary act or as a result of HR managerial policies, (3) sources of motivation, (4) implementation of motivation (5) personal views about motivation techniques and (6) the personal views regarding atypical motivation techniques.

First, table 3 presents a summary of the definitions of motivation as reported by directors. This helps better analyze them, draw conclusions and offer useful recommendations for motivation of employees in the public sector.

Table 3. Defining Employee Motivation (Directors' Interview)

\begin{tabular}{l|l}
\hline Director & Definition of employee motivation \\
\hline Director 1 & Einistry of Higher \\
Education & $\begin{array}{l}\text { Continuous incentives } \\
\text { Certificate of appreciation } \\
\text { Continuous meetings } \\
\text { Moral stimulus }\end{array}$ \\
\hline $\begin{array}{l}\text { Director 2 } \\
\text { Ministry of Electricity }\end{array}$ & $\begin{array}{l}\text { Employee motivation is the fact of working happily for the company, } \\
\text { its future, its general interest and objectives. }\end{array}$ \\
\hline
\end{tabular}

It is clear that the definition of motivation for these two directors is very different. Each one defined employee motivation from a different point of view which can be seen as enrichment for the results allowing to a better understanding of the motivation.

Table 4 below discusses the origin of motivation as viewed by these two directors.

Table 4. Employee Motivation as a Voluntary Act or as a Result of HR Managerial Policies (Directors' Interview)

\begin{tabular}{l|l}
\hline Director & $\begin{array}{l}\text { Employee Motivation as a Voluntary Act or as a Result of HR Managerial } \\
\text { Policies }\end{array}$ \\
\hline $\begin{array}{l}\text { Director 1 } \\
\text { Ministry }\end{array}$ of & It is an act that comes from the interaction between the two. \\
Education & \\
\hline $\begin{array}{l}\text { Director 2 } \\
\text { Ministry of } \\
\text { Electricity }\end{array}$ & $\begin{array}{l}\text { Employee is mainly a result of HR management. The direction of the HR } \\
\text { must take into consideration the personality and attitude of the employees, } \\
\text { and work to help and motivate people who have problems and unmotivated } \\
\text { characters. }\end{array}$ \\
\hline
\end{tabular}

Thus the two directors have different point of views. It is observed that the first director thinks that the origin of employee motivation is a mixture of the employee himself, his behavior and personality towards work, and the HR management while director 2 judges that HR management is solely responsible of motivating employees.

Table 5 presents a summary of the factors affecting employee motivation in the public sector. 
Table 5. Employee Motivation Sources (Directors' Interview)

\begin{tabular}{|c|c|}
\hline Director & Employee Motivation Sources \\
\hline $\begin{array}{l}\text { Director } 1 \\
\text { Ministry of Higher Education }\end{array}$ & $\begin{array}{l}\text { Compensation } \\
\text { Working conditions } \\
\text { Participation in decisions } \\
\text { Team spirit } \\
\text { Promotion } \\
\end{array}$ \\
\hline $\begin{array}{l}\text { Director } 2 \\
\text { Ministry of Electricity }\end{array}$ & $\begin{array}{l}\text { Promotion and Pay } \\
\text { Working conditions } \\
\text { Autonomy }\end{array}$ \\
\hline
\end{tabular}

By observing the collected data, one can notice that according to these guidelines, classification of sources of motivation is very different and diverse. This can be explained by the difference in the types of business, the status within the organization, the age and experience of the respondents.

Table 6 helps to know if the government applies employee motivation policies.

Table 6. Existence of Employee Motivation Policy (Directors' Interview)

\begin{tabular}{l|l}
\hline Director & Existence of Employee Motivation Policy \\
\hline $\begin{array}{l}\text { Director 1 } \\
\text { Ministry of Higher }\end{array}$ & There is no policy and motivational techniques in this organization. \\
Education & \\
\hline $\begin{array}{l}\text { Director 2 } \\
\text { Ministry of Electricity }\end{array}$ & $\begin{array}{l}\text { There is no employee motivation policy within the organization. } \\
\text { Sometimes some training programs are offered. }\end{array}$ \\
\hline
\end{tabular}

Thus, there is no policy applied for increasing employee motivation in the public sector.

Table 7 concerns the point of view of the directors in relation to motivational techniques.

Table 7. Employee Motivation Techniques (Directors' Interviews)

\begin{tabular}{|c|c|}
\hline Director & Employee Motivation Techniques \\
\hline $\begin{array}{l}\text { Director } 1 \\
\text { Ministry of Higher } \\
\text { Education }\end{array}$ & $\begin{array}{l}\text { Offering training programs } \\
\text { Organizing meetings continuously } \\
\text { listening to employees } \\
\text { Providing good communication policies }\end{array}$ \\
\hline $\begin{array}{l}\text { Director } 2 \\
\text { Ministry of Electricity }\end{array}$ & No answer \\
\hline
\end{tabular}

Table 8 represents the point of view of directors concerning the atypical employee motivation techniques.

Table 8. Atypical Employee Motivation Techniques (Directors' Interviews)

\begin{tabular}{|c|c|}
\hline Director & Atypical Employee Motivation Techniques \\
\hline $\begin{array}{l}\text { Director } 1 \\
\text { Ministry of Higher } \\
\text { Education }\end{array}$ & $\begin{array}{l}\text { All standard forms of employee motivation techniques are quite } \\
\text { positive and interesting. They allow employees to clear their mind. }\end{array}$ \\
\hline $\begin{array}{l}\text { Director } 2 \\
\text { Ministry of Electricity }\end{array}$ & $\begin{array}{l}\text { These new employee motivation techniques are very positive for the } \\
\text { organization and for the employee at the same time. }\end{array}$ \\
\hline
\end{tabular}

Thus according to Table 8 , both directors are with these new motivational techniques. 


\subsubsection{Cross-Analysis of Responses between Employees}

This analysis is divided into several parts to gather all the topics discussed. These topics are (1) concept of employee motivation, (2) employee motivation as a voluntary act or as a result of HR managerial policies, (3) sources of motivation, (4) implementation of motivation (5) personal views about motivation techniques and (6) the personal views regarding atypical motivation techniques.

First, concerning the definition of employee motivation, table 9 represents the point of view of the three employees interviewed.

Table 9. Defining Employee Motivation (Employees' Interview)

\begin{tabular}{|c|c|}
\hline Employee & on of Employee Motivati \\
\hline $\begin{array}{l}\text { Employee } 1 \\
\text { Bank of Lebanon }\end{array}$ & $\begin{array}{l}\text { e motivation is an essential element to ensure a good image } \\
\text { nk and provide a positive environment for employees. }\end{array}$ \\
\hline $\begin{array}{l}\text { employee } 2 \\
\text { Ministry of Finance }\end{array}$ & $\begin{array}{l}\text { on is informing employees about the work to do it and to } \\
\text { the quality of work, while also increasing their salary. }\end{array}$ \\
\hline $\begin{array}{l}\text { Employee } 3 \\
\text { Ministry of Higher } \\
\text { Education }\end{array}$ & $\begin{array}{l}\text { The motivation of employees is shown by the success and } \\
\text { understanding of the students in his class, and good communication } \\
\text { with them allows them to be motivated in their work. }\end{array}$ \\
\hline
\end{tabular}

From this table, one can notice that each employee defined motivation differently but each definition completes the others. This allows realizing that employees are aware of the importance of motivation at work.

In addition, the difference between the definitions of employee motivation comes from the status of the interviewee, age and work experience. Indeed, the three people interviewed are not identical when the first employee is fifty years' old with twenty years of experience; the second employee is fifty nine years' old with thirty years of experience and the third employee is twenty eight years' old and has seven years of experience in a public school. Finally, the companies in which the three employees work are also different when the first employee works at the Bank of Lebanon, the second holds a position of cashier in the Ministry of Finance, and the third is a teacher in the Ministry of Higher Education.

In terms of employee motivation as a voluntary act or as pushed by HR management, Table 10 presents the opinion of the three employees interviewed about the origin of employee motivation.

Table 10. Employee Motivation as a Voluntary Act or as a Result of HR Managerial Policies (Employees' Interview)

\begin{tabular}{l|l}
\hline Employee & $\begin{array}{l}\text { Employee Motivation as a Voluntary Act or as a Result of HR } \\
\text { Managerial Policies }\end{array}$ \\
\hline $\begin{array}{l}\text { Employee 1 } \\
\text { Bank of Lebanon }\end{array}$ & $\begin{array}{l}\text { Employee motivation comes from the employees themselves but also } \\
\text { HR directors must be fair and treat employees equally and must } \\
\text { ensure a good positive climate for them because the bad environment } \\
\text { and inequalities in the labor negatively affect their progress. }\end{array}$ \\
\hline $\begin{array}{l}\text { Employee 2 } \\
\text { Ministry of Finance }\end{array}$ & $\begin{array}{l}\text { It is necessary to have an interactive relationship between the } \\
\text { employee and HR policy. When the employee has the desire to grow } \\
\text { and to be motivated in his work, HR policy must adopt certain } \\
\text { policies for him to ensure that motivation. }\end{array}$ \\
\hline $\begin{array}{l}\text { Employee 3 } \\
\text { Ministry of Higher } \\
\text { Education }\end{array}$ & $\begin{array}{l}\text { The motivation of employees may be voluntary but bad leadership } \\
\text { has negative effects resulting in de-motivating employees. }\end{array}$ \\
\hline
\end{tabular}


Thus, according to the three employees, the origin of employee motivation is a mixture of the inner self of the employee and the HR policies applied at work.

The major sources of employee motivation are presented in table 11 below.

Table 11. Employee Motivation Sources (Employees' Interview)

\begin{tabular}{l|l}
\hline Employee & Employee Motivation Sources \\
\hline Employee 1 & Salary and remuneration benefits \\
Bank of Lebanon & Coaching \\
\hline Employee 2 & Compensation \\
Ministry of Finance & Working conditions \\
& Work content \\
& Relationships at work and communication \\
\hline Employee 3 & Salary \\
Ministry of Higher Education & Working conditions \\
& Promotion \\
& Participation in decisions \\
\hline
\end{tabular}

As we can see in this scale that the classification of sources of motivation varies with each interviewee and this amounts to the different positions of the latter. Indeed, this difference allows us to infer the importance of all these features of work and allows us to better understand the factors that have the greatest effect on the motivation of employees.

Concerning the employee motivation policies, table 12 discusses the existence of these latter in the public sector organizations.

Table 12. Existence of Employee Motivation Policy (Employees' Interview)

\begin{tabular}{l|l}
\hline Employee & Existence of Employee Motivation \\
\hline $\begin{array}{l}\text { Employee 1 } \\
\text { Bank of Lebanon }\end{array}$ & $\begin{array}{l}\text { Despite all the anomalies that have been cited before, the } \\
\text { management offers training at the bank to inform employees of any } \\
\text { new. }\end{array}$ \\
\hline $\begin{array}{l}\text { Employee 2 } \\
\text { Ministry of Finance }\end{array}$ & $\begin{array}{l}\text { The state does not adopt motivational techniques for employees, but } \\
\text { despite it has once applied a policy of motivation by giving a bonus to } \\
\text { an employee who can invent a method to develop the work. }\end{array}$ \\
\hline $\begin{array}{l}\text { Employee 3 } \\
\text { Ministry of Higher } \\
\text { Education }\end{array}$ & $\begin{array}{l}\text { There is a lack of policies implemented by the state to motivate } \\
\text { employees. }\end{array}$ \\
\hline
\end{tabular}

Thus, the implementation of employee motivation policy is not the priority of public organizations specifically. They do not adopt any kind of policy, although some elements were applied to motivate employees but were not enough because of other problems that must be addressed and taken into consideration to motivate them.

Concerning the different techniques of motivation proposed by employees, Table 13 below shows the different point of views which can clearly indicate that all the employees understand well the importance of motivation and how they can be motivated. 
Table 13. Employee Motivation Techniques (Employees' Interviews)

\begin{tabular}{l|l}
\hline Employee & Employee Motivation Techniques \\
\hline Employee 1 \\
Bank of Lebanon & $\begin{array}{l}\text { Adopt a policy of equality between the various employees, while } \\
\text { penalizing those who do not do their mission. } \\
\text { Put the right person in the right place. } \\
\text { Give bonuses for skilled employees, making them more motivated in } \\
\text { their work. } \\
\text { Ensure a good climate in the workplace. }\end{array}$ \\
\hline $\begin{array}{l}\text { Employee 2 } \\
\text { Ministry of Finance }\end{array}$ & $\begin{array}{l}\text { Promote contact between the HR department and employees } \\
\text { Stop the random recruitment which causes a problem for employees } \\
\text { and the state simultaneously. }\end{array}$ \\
\hline $\begin{array}{l}\text { Employee 3 } \\
\text { Ministry of Higher } \\
\text { Education }\end{array}$ & $\begin{array}{l}\text { Apply a control policy while giving each person what he or she } \\
\text { deserves. } \\
\text { Give bonuses to those who have made progress during the year and } \\
\text { sanction those who do not do their job properly. }\end{array}$ \\
\hline
\end{tabular}

Finally, table 14 shows the point of view of employees in relation to atypical motivation techniques.

Table 14. Atypical Employee Motivation Techniques (Employees’ Interviews)

\begin{tabular}{l|l}
\hline Employee & Atypical Employee Motivation Techniques \\
\hline Employee 1 \\
Bank of Lebanon & $\begin{array}{l}\text { Some ideas of atypical techniques could be: } \\
\text { Putting a microphone to facilitate communication with employees. } \\
\text { Providing rest times for employees while making comfortable living } \\
\text { rooms. }\end{array}$ \\
\hline $\begin{array}{l}\text { Employee 2 } \\
\text { Ministry of Finance }\end{array}$ & $\begin{array}{l}\text { All of these new types of motivational techniques are very interesting } \\
\text { because they have a positive effect for employees and businesses } \\
\text { where it increases profit and performance. }\end{array}$ \\
\hline $\begin{array}{l}\text { Employee 3 } \\
\text { Ministry of Higher }\end{array}$ & $\begin{array}{l}\text { It is essential to apply this type of policy so as to motivate employees } \\
\text { at work. This can be achieved through: } \\
\text { Improving infrastructure and the building of the public organization. } \\
\text { Buying all the technological equipment and ensuring development. } \\
\text { Providing a gym and a library. }\end{array}$ \\
\hline
\end{tabular}

According to this table, one can notice that each employee has his or her own suggestions that differ from others and this is because of the different workplaces of each.

In addition, it is important to mention that all these proposals cannot be implemented in reality because the state limit these activities and does not offer sufficient budgets for all these developments and changes.

\subsubsection{Cross Analysis: Directors / Employees}

After completing the cross-analysis of interviews for employees on the one hand and for directors on the other hand, the focus now is on the cross-analysis of data collected between directors and employees, while analyzing in first place commonalities between directors and employees then secondly discussing the points of differences presented in the previous analysis.

Regarding the common points, employees and directors seem to agree on many major points. Indeed, both believe that employee motivation comes from the employees themselves and that the policy applied within each organization plays a critical role in employee motivation 
as well. Regarding motivation techniques adopted by these organizations, directors and employees emphasized the same point of view that the state does not motivate them and does not adopt the employee motivation policies in the public sector and de-motivate them because they are not comfortable at work, although some activities are implemented but this is not enough because there are many problems in the work that the state must solve and consider to improve all the conditions of work with each person. So, based on what they said, there is a great shortage of employees' motivational techniques in public organizations.

In addition, regarding new atypical motivation techniques, directors and employees have adopted the same view that these techniques are of great benefit to them and for the organization at the same time, ensuring its growth. Thus, notwithstanding they presented different proposals, but it all comes back to the same point that the application of these techniques is important and essential for the development and motivation of employees in their work.

Concerning the points of divergence, each respondent defined motivation differently but they all complemented each other and this difference was the result of the difference age and work status of the respondent and the different type of organization for each respondent.

Finally, concerning the classification of employee motivation sources, directors and employees do not agree on the same sources of motivation, but all the collected data are very logical, interesting and helps motivation, for that all the proposed sources are essential features for employee motivation to work. This diversity of sources of motivation is a strong point allowing taking a broader perspective on the characteristics and sources of motivation at work.

\section{Conclusion}

This research study aims to identify the job characteristics that are key determinants of motivation in the Lebanese public sector. In this context, an overview of the different concepts of motivation and the various theories related to motivation and job satisfaction along with an overview of the functioning of public organizations in Lebanon were examined. Then, a qualitative research was applied through interviewing five respondents working in the public sector of Lebanon. This allowed to establish themes and to address more profoundly the subject of study. Through analyzing the results of data collected from interviews conducted with directors and employees, a comparative analysis of the various results was carried out.

These various analyses and results helped to verify that job characteristics are key determinant of motivation in the public sector of Lebanon. Indeed, employees and directors classified the most important job characteristics factors in terms of their effect on motivation. These characteristics are: remuneration, working conditions, promotion, autonomy, participation in decisions, work social relationships and communication. Remuneration and working conditions are key to higher employee motivation. Promotion, autonomy, participation in decisions, work social relationships and communication should be considered as well. 
In addition, these results enabled to identify some other determinants that were considered as factors affecting motivation but these were not approved by directors and employees and thus were rejected. Note that these are the other determinants of labor market factors such as the existence of labor unions that protect the rights of employees, and the adequacy of supply and demand for jobs.

Besides, these analyses have enabled the development of a number of recommendations. Though job characteristics were identified as major determinants of motivation, the Government didn't do any effort to provide these characteristics. Thus, recommendations aim to encourage the legal authorities to improve the job characteristics that were deemed to influence employee motivation, and as aforementioned, are a success factor in the business. These recommendations are: 1) to establish an independent institution capable of defending the employee against the administration of legal authorities, since governments are expected to ensure the rights of their workers and to provide them a healthy work environment; 2) to place the right person in the right place and to hire only competent persons, which in the long run reduces costs and improves performance; 3) to increase wages especially that employees and directors have agreed that the salary is the most important factor that motivates them at work; 4) to adopt a clear policy to give bonus for employees who make a progress during the year; and finally 5) to ensure a sufficient budget for the development of public organizations, because this is the main reason why governments do not support all the activities aforementioned.

Furthermore, public organizations suffer from a lack of technology in most sectors and all used materials are old and not working properly, hence the need to encourage the state to consider all these reforms and to try improve working conditions is considered as a first step towards a more enlightened future and more motivated employees.

\section{References}

Alderfer, C. P. (1969). An Empirical Test of a New Theory of Human Needs. Organizational Behavior and Human Performance, 4(2), 142-175. https://doi.org/10.1016/0030-5073(69)90004-X

Crozier , M. (1987). The Problems of Public Management. Les Cahiers French, 233, 53-55.

Crozier, M. (1987). Public Management of the Problems Facing the Transformation of the Environment. Policies and Public Management Review, 3(1), 9-23.

Dagemais, B. (2005). The Job of Public Relations. The Press of Laval University, 5th edition.

Dagher, A. (2010). The Lebanese Administration after 1990. The Press Laval University, 3.

Deci, E. L., \& Ryan, R. M. (1985). Intrinsic Motivation and Self-determination in Human Behavior. New York, NY: Plenum. https://doi.org/10.1007/978-1-4899-2271-7

Dizgah, M. R., Chegini, M. G., \& Bisokhan, R. (2012). Relationship between Job Satisfaction and Job Performance in Guilan Public Sector. Journal of Basic and Applied Scientific Research, 2(2), 1735 - 1741. 
Ghaziani, F. G., Safania, A., \& Tayebi, S. M. (2012). Impact of Organizational Justice Perceptions on Job Satisfaction and Organizational Commitment: The Iran's Ministry of Sport Perspective. Australian Journal of Basic and Applied Sciences, 6(7), 179 - 188.

Gradišar, N. (2009). Primerjava orodij za merjenje organizacijske klime in zadovoljstva zaposlenih v javnem in zasebnem sektorju (Comparison of tools for measuring organizational climate and employee satisfaction in the public and private sectors). Undergraduate thesis. Ljubljana: Faculty of Social Sciences.

Hackman, J. R., \& Oldham, G. R. (1976). Motivation through the Design of Work: Test of a Theory. Organizational Behavior and Human Performance, 16, 250-279. https://doi.org/10.1016/0030-5073(76)90016-7

Hackman, J. R., \& Oldham, G. R. (1980). Work Redesign. Addison-Wesley.

Hemming, K., Girling, A. J., Stieh, A., Marsh, J., \& Lilford, R. J. (2011). Sample Size Calculations for Cluster Randomized Controlled Trials with a Fixed Number of Clusters. BMC Medical Research Methodology, 11, 102. https://doi.org/10.1186/1471-2288-11-102

Herzberg, F., Mausner, B., \& Snyderman, B. B. (1959). The Motivation to Work. New York, John Wiley.

Hofstede, G., Hofstede, J. G., \& Minkov, M. (2010). Cultures and Organizations: Software of the Mind. Revised and Expanded 3rd Edition. New York: McGraw-Hill USA.

Hsu, M., \& Chen, K. (2012). A Study of the Relationship among Self-Motivation, Organizational Commitment and Job Satisfaction of University Faculty Members in Taiwan. International Journal on New Trends in Education and their Implications, 3(3), 7.

Jex, S. M., \& Britt, T. W. (2008). Organizational Psychology. Hoboke. New Jersey: John Wiley and Sons Inc.

Kosteas, V. D. (2010). Job Satisfaction and Promotions. Industrial Relations: A Journal of Economy and Society, 50(1), 174 - 194. https://doi.org/10.1111/j.1468-232X.2010.00630.x

Laufer, R. (1985). Governability and Management of Complex Administrative Systems. Policies and Public Management Review, 3(1), 25 - 48.

Lee, C., \& Lee, J. (2012). Analysis of the Relationships between the Hospitality Workforce and Job-Satisfaction Factors according to Age, Gender, Native Language and Racial Ethnicity. Tourism and Hospitality, 1(5). https://doi.org/10.4172/2167-0269.1000104

Levy, L. C. (1998). The motivation in the Company. Ed. Organization, Paris.

Locke, E. A. (1968). Toward a Theory of Task Motivation and Incentives. Organizational Behavior and Human Performance, 3(2), 157-189. https://doi.org/10.1016/0030-5073(68)90004-4

Maslow, A. (1943). A Theory of Human Motivation. The Psychological Review, 50(4), 370-396. https://doi.org/10.1037/h0054346 
McClelland, D. C. (1961). The Achieving Society. Princeton, Van Nostrand. https://doi.org/10.1037/14359-000

Mercier, E. (2000). The Effects of Modernization on Human Resources Management Practices in Public Utility Companies. A Conventionalist Reading of the Evolutionary Process to RATP and EDF-Lorraine. PhD in Management Science, Thesis Direction G. Schmidt.

Mokaya, S. O., Musau, J. L., Wagoki, J., \& Karanja, K. (2013). Effects of Organizational Work Conditions on Employee Job Satisfaction in the Hotel Industry in Kenya. International Journal of Arts and Commerce, 2(2).

Naveed, A., Usman, A., \& Bushra, F. (2011). Promotion: A Predictor of Job Satisfaction A Study of Glass Industry of Lahore (Pakistan). International Journal of Business and Social Science, 2(16), $301-305$.

Reix, R. (2000). Information System and Organization Management. Third Edition, Vuibert, Paris.

Roussel, P. (2000). The Motivation to Work - Concepts and Theories. Notes LIRHE, 326.

Roussel, P. (2001). Work Motivation: Concepts and Theories. Ed. EMS, Paris.

Sehgal, M. S. (2012). Job Satisfaction of Bank Employees in Shimla: A Comparative Study of Private and Public Sector Bank (Axis Bank and UCO Bank). International Journal of Marketing, Financial Services and Management Research, 1(7).

Serhan, C., \& Tsangari, H. (2015). Retention of fresh graduates: Identification of determinant factors through a modified job characteristics model. Proceedings of the Global Business Conference (CBC 2015), Sibenik, Croatia, 200-202.

Serhan, C., \& Tsangari, H. (2016a). The Inclusion of Labor Market Conditions in a Proposed Modeling Framework for Fresh Graduates' Retention. Journal of Research in Business Economics and Management, 7(3), 1107 - 1121.

Serhan, C., \& Tsangari, H. (2016b). Modeling the Effect of Core Job Dimensions and Labor Market Conditions on Fresh Graduates' Retention. International Journal of Recent Advances in Organizational Behaviour and Decision Sciences, 2(2), 763 - 771.

Serhan, C., \& Tsangari, H. (2017). Development of a Theoretical Framework for Retaining Fresh Graduates through Job Satisfaction. Proceedings of the $23^{\text {rd }}$ Scientific International Conference: Research and Science in the Service of Humanity, Beirut, Lebanon, 28-30.

Serhan, C., Tsangari, H., Sanchez, B. D., \& Mekdessi, S. (2016). Fresh graduates' retention: A review of literature. IOSR Journal of Business and Management, 18(2), 51 - 64.

Tourani, A., \& Rast, S. (2012). Effect of Employees' Communication and Participation on Employees Job Satisfaction: An Empirical Study on Airline Companies in Iran. International Conference on Economics, Trade and Development. IPEDR. 36. IACSIT Press, Singapore.

Vallerand, R. J., \& Thill, E. E. (1993). Introduction to the Concept of Motivation. Introduction 


\section{Macrothink}

International Journal of Human Resource Studies

ISSN 2162-3058 2018, Vol. 8, No. 1

to the Psychology of Motivation, Laval (Quebec) Editions living studies, 18.

Vroom, V. H. (1964). Work and Motivation. Wiley, New York.

Zakaria, S. (2012). Ways to Make Fresh Graduates Employable. Gulf News, June 30. Downloaded on 13 February 2014 from: http://gulfnews.com/business/my-career/ways-to-make-fresh-graduates-employable-1.104197 8

Zeytinoglu, I. U., \& Denton, M. (2005). Satisfied workers, retained workers: Effects of work and work environment on homecare workers' job satisfaction, stress, physical health, and retention. (CHSRF FCRSS: Canadian Health Services Research Foundation), 210 - 245.

\section{Copyright Disclaimer}

Copyright for this article is retained by the author(s), with first publication rights granted to the journal.

This is an open-access article distributed under the terms and conditions of the Creative Commons Attribution license (http://creativecommons.org/licenses/by/4.0/). 